\title{
KAJIAN NUMERIK STRUKTUR RANGKA TERBREIS EKSENTRIK DENGAN LINK YANG DAPAT DIGANTI
}

\author{
Nugraha Bintang Wirawan ${ }^{1}$ \\ ${ }^{1}$ Program Studi Teknik Sipil, Institut Teknologi Sumatera, Lampung, Indonesia
}

\begin{abstract}
:
The Eccentric Braced Frame (EBF) is an earthquake resistant building system that has advantages in terms of strength and stiffness and has good ductility and energy dissipation capability in inelastic condition. Links are the most important elements that serve to dissipate the energy of the earthquake through the inelastic behavior of the structure. The performance of shear links is strength, stiffness, ductility and energy dissipation depending on the cross-sectional profile used on the link. This study aims to determine the relation behavior of RTE structures with links using bolt connections made of a variety of steel grades as well as applying Side Extended Plate (SEP) and those without SEP. The analysis was done using MSC PATRAN / NASTRAN software. As a total of eight link model variations were assessed to determine the most optimum performance of the structure when monotonic and cyclic static loading was carried out with displacement control. The results indicate that variations in the quality of the linked steel on the wing plate and body plate can significantly increase the strength, stiffness, and ductility of the structure compared with the use of SEP.
\end{abstract}

Keyw: $\quad$ The Eccentric Braced Frame, shear link, bolt and weld joint links, variations steel quality, and Side Extended Plate

\section{Pendahuluan}

Penggunaan baja sebagai elemen struktur saat ini sudah menjadi pilihan dalam mendirikan bangunan tahan gempa karena memiliki kekuatan dan daktilitas yang sangat baik. Namun demikian, sifat daktail dari baja tidak dapat secara langsung dihubungkan dengan perilaku struktur yang daktail. Untuk menjamin struktur baja berperilaku daktail dan mampu menyerap energi gempa melalui terbentuknya kelelehan pada bagian struktur tertentu, maka harus diperhatikan desain dan detailing dari setiap komponen struktur.

Ada beberapa sistem struktur baja tahan gempa yang lazim digunakan, yaitu : 1. Sistem Rangka Momen (RM), 2. Sistem Rangka Terbreis Konsentris (RTK), 3. Sistem Rangka Terbreis Eksentris (RTE) atau Eccentric Braced Frame (EBF). Dari hasil riset yang pernah dilakukan berbagai peneliti, sistem Rangka Terbreis Eksentris lebih unggul dari segi kekuatan, kekakuan, daktilitas dan kemampuan mendisipasi energi dibandingkan sistem lainnya. Pada sistem RTE, perilaku daktail diperoleh dari peristiwa leleh pada link tanpa memperbolehkan elemen struktur lainnya mengalami kelelehan ataupun tekuk. Kekakuan lateral dari sistem RTE merupakan fungsi dari panjang link terhadap balok di luar link (balok utama). Semakin pendek link maka kekakauan lateral struktur menjadi semakin besar, sedangkan semakin panjang link maka kekakuan lateral struktur pun menjadi semakin kecil sehingga rangka menjadi lebih fleksibel seperti pada sistem RM.

Kelelehan pada link dapat berupa kelelehan geser ataupun kelelehan lentur. Adapaun jenis link berdasarkan panjang dan sifat kelelehan yaitu sebagai berikut :

a. Link geser murni, e $\leq 1.6 \mathrm{Mp} / \mathrm{Vp}$ : Kelelehan link didominasi oleh geser.

b. Link dominan geser, $1.6 \mathrm{Mp} / \mathrm{Vp}<\mathrm{e} \leq 2.6 \mathrm{Mp} / \mathrm{Vp}$ : Kelelehan link kombinasi antara geser dan lentur

c. Link lentur murni e > 2.6 Mp/ $\mathrm{Vp}$ : Kelelehan link didominasi oleh lentur

di mana :

$\mathrm{M}_{\mathrm{p}}=\mathrm{F}_{\mathrm{y}} \cdot \mathrm{Z}_{\mathrm{x}}$

$V_{p}=0,6 \cdot F_{y} \cdot A_{w}$

$A_{w}=\left(d-2 t_{f}\right) \cdot t_{w}$

Keterangan :

$\mathrm{M}_{\mathrm{p}} \quad$ : Momen plastis/momen yang menyebabkan seluruh penampang leleh

$V_{p} \quad$ : Gaya geser plastis/gaya geser yang menyebabkan seluruh penampang web leleh 
$F_{y} \quad:$ Tegangan leleh baja

$Z_{x} \quad$ : Modulus plastis penampang

e : Panjang link

Berdasarkan kajian yang telah dilakukan oleh [1], diperoleh hasil bahwa link geser atau link pendek paling baik dalam menahan gaya gempa ditinjau dari segi kekuatan, kekakuan dan daktilitas. Semakin pendek link maka semakin besar sudut rotasi yang terjadi pada link. Besarnya sudut rotasi harus dibatasi untuk menjamin deformasi inelastik yg terjadi pada struktur akibat gempa tidak melebihi kapasitas deformasi inelastik link. Penentuan sudut rotasi inelastik dari link dapat dilihat dari Gambar 1.

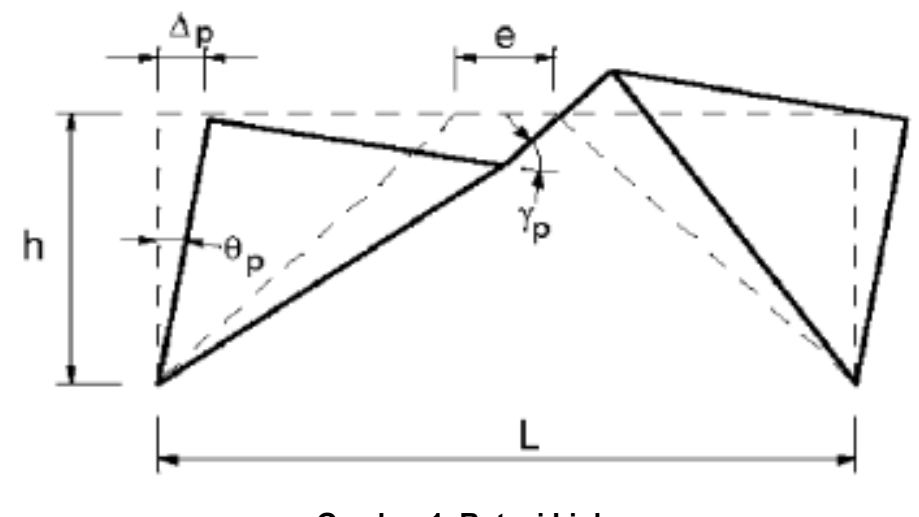

Gambar 1. Rotasi Link

Untuk menghitung sudut rotasi link digunakan rumus berikut:

$\gamma_{p}=\frac{L}{e} \theta_{p}$

$\theta_{p}=\frac{\Delta_{\mathrm{p}}}{h}$

Keterangan :

L : : lebar bentang

h $\quad$ : Tinggi lantai

$\Delta_{\mathrm{p}} \quad$ : Story drift rencana

$\theta_{\mathrm{p}} \quad$ : Sudut perpindahan plastis

$\gamma_{p} \quad:$ Sudut rotasi link

Sudut rotasi tidak boleh melebihi nilai-nilai berikut :

a. 0.08 radian untuk link dengan panjang $1.6 \mathrm{MP}_{\mathrm{P}} / \mathrm{V}_{\mathrm{P}}$ atau kurang.

b. 0.02 radian untuk link dengan panjang $2.6 \mathrm{MP}_{\mathrm{P}} / \mathrm{V}_{\mathrm{P}}$ atau lebih.

c. Untuk link dengan panjang di antara $1.6 \mathrm{M}_{\mathrm{P}} / \mathrm{V}_{\mathrm{P}}$ dan $2.6 \mathrm{M}_{\mathrm{P}} / \mathrm{V}_{\mathrm{P}}$ harus dilakukaninterpolasi.

Sambungan juga menentukan kinerja link. Ada dua macam sambungan yang biasa digunakan yaitu sambungan las dan sambungan baut.Selama ini jenis sambungan link yang lebih sering digunakan yaitu sambungan las. Namun sambungan jenis ini memiliki beberapa kelemahan yang mempengaruhi kinerja link. Dengan adanya kelemahan pada sambungan las maka kajian terhadap kinerja link dengan sambungan baut mulai dikembangkan. Pemakaian sambungan baut dapat mempermudah untuk mengganti link apabila rusak akibat beban siklik seperti gempa, dengan catatan tidak terjadi kerusakan pada elemen selain link. [2] melakukan kajian ekperimental link geser dengan sambungan baut yang direncanakan untuk struktur RTE bangunan ruko tiga lantai menggunakan bresing tipe splitK. Pembebanan siklik dengan kontrol perpindahan dilakukan sampai link mengalami kegagalan. Hasil kajian menunjukkan bahwa pinching yang terjadi pada kurva histeresis dapat diperbaiki dengan cara menggunakan diameter baut yang lebih besar untuk mencegah semakin lebarnya bukaan antar pelat yang disambung pada saat baut mengalami tarik. 
Link geser dapat bekerja secara optimum sebagai pendisipasi energi apabila tidak terjadi kelelehan pada pelat sayap. [3] melakukan kajian eksperimental penggunaan pelebaran pelat sayap pada kedua ujung link (Side Extended Plate/SEP) dapat menunda kegagalan tekuk pada pelat sayap karena luasan pelat sayap semakin bertambah dengan adanya pelebaran sehingga konsentrasi tegangan pada pelat sayap dapat lebih disebarkan ke area yang lebih luas. Dengan demikian tegangan yang bekerja pada pelat sayap semakin kecil sehingga kegagalan akan lebih dahulu terjadi pada pelat badan. Selain menggunakan SEP, [4] melakukan kajian eksperimental dengan menambahkan inovasi penggunaan profil link penampang tersusun yang menggunakan mutu pelat sayap yang lebih tinggi daripada pelat badan (link hibrid). Hasil kajian menunjukkan bahwa penggunaan link dengan pelat sayap bermutu lebih tinggi daripada pelat badan link dapat mencegah terjadinya leleh awal dan kegagalan awal akibat fraktur pada pelat sayap, dan sekaligus mendorong pelelehan yang lebih maksimal dan merata pada pelat badan link.

[5] melakukan kajian eksperimental dengan benda uji struktur portal RTE dengan link geser menggunakan sambungan las dan baut serta menggunakan mutu pelat sayap yang lebih tinggi daripada pelat badan. Hasil kajian menunjukkan bahwa penggunaan sambungan baut pada link hanya memberikan perbedaan yang kecil jika dibandingkan dengan link yang menggunakan sambungan las terutama dalam hal energi disipasi.

Walaupun sudah ada kajian yang membahas mengenai kombinasi penggunaan pelebaran pelat sayap pada ujung link dan mutu pelat sayap yang lebih tinggi daripada pelat badan, namun variasi model yang diuji tidak banyak. Oleh karena itu pada makalah ini dibahas kajian numerik struktur RTE dengan menggunakan link geser yang mengombinasikan variasi mutu baja pada pelat sayap dan pelat badan (link hibrid) serta penggunaan SEP pada model sambungan link yang menggunakan baut. Analisis dilakukan terhadap parameter kekakuan, kekuatan, daktilitas, faktor kuat lebih, sudut rotasi link, dan energi disipasi.

\section{Kajian Numerik}

\section{Dasar Pemodelan Struktur}

Kajian numerik dilakukan dengan mengambil studi kasus pada bangunan ruko 3 lantai berukuran 36 meter x 12 meter yang berlokasi di Bandar Lampung. Struktur yang dimodelkan terdiri dari : 9 bentang arah $X$ dengan jarak antar bentang yaitu 4 meter, 2 bentang arah $Z$ dengan jarak antar bentang yaitu 6 meter, dan tinggi antar lantai sebesar 4 meter. Portal RTE tipe split K dipasang setiap 12 meter pada arah sejajar sumbu-Z, seperti terlihat pada Gambar 2. Elemen link didesain mengikuti peraturan Pembebanan untuk Perancangan Bangunan Gedung dan Struktur Lain [6], peraturan Perencanaan Ketahanan Gempa untuk Struktur Bangunan Gedung dan Non Gedung [7], dan peraturan Spesifikasi untuk Bangunan Gedung Baja Struktural [8] beserta turunannya.

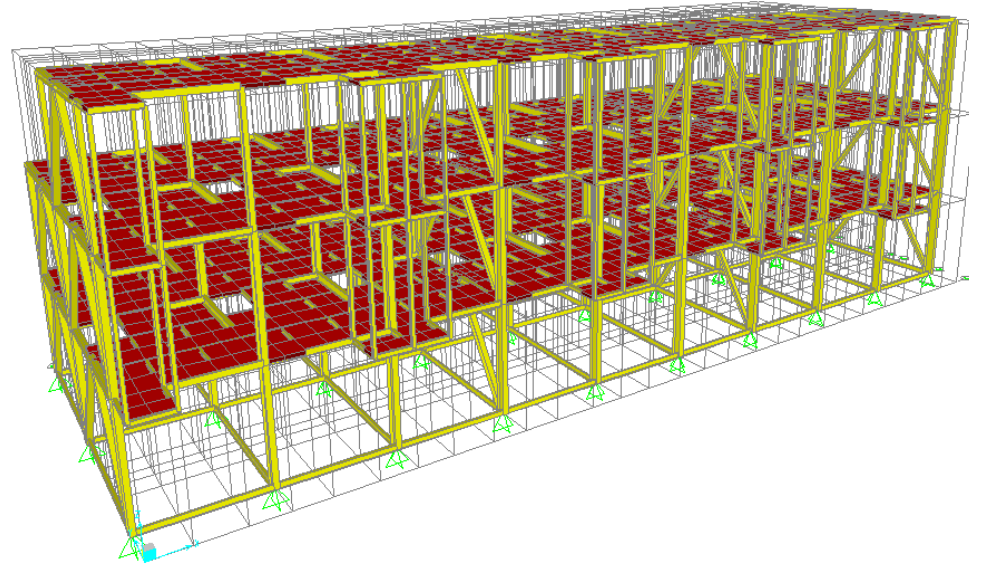

Gambar 2. Pemodelan Struktur Ruko 3 Lantai 


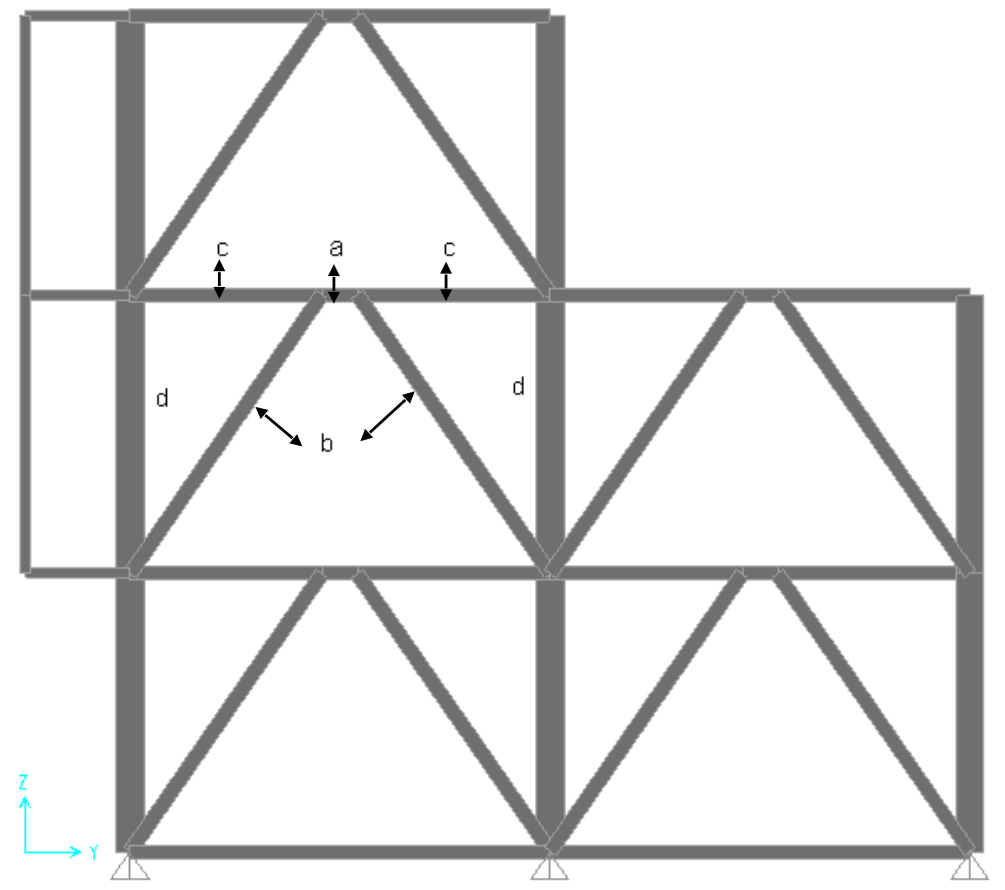

Gambar 3. Penampang Melintang Struktur Ruko 3 Lantai

Dengan bantuan perangkat lunak, diperoleh dimensi penampang struktur portal 2 dimensi yang dapat dilihat pada Gambar 3 dan Tabel 1.

Tabel 1. Dimensi Penampang Elemen Struktur Skala Penuh

\begin{tabular}{|l|l|}
\hline \multicolumn{1}{|c|}{ Elemen Struktur } & \multicolumn{1}{c|}{ Dimensi Penampang } \\
\hline Link (a) & IWF 200.100.5,5.8 \\
\hline Bracing (b) & IWF 200.100.5,5.8 \\
\hline Balok (c) & IWF 200.100.5,5.8 \\
\hline Kolom (d) & IWF 400.200 .8 .13 \\
\hline Pengaku link (linkstiffener) & Pelat tebal $10 \mathrm{~mm}$ \\
\hline Jumlah pengaku/stiffener setiap sisi & 3 buah \\
\hline Pelat ujung sambungan baut & Tebal $30 \mathrm{~mm}$ \\
\hline Diameter baut & $19 . \mathrm{m}$ \\
\hline
\end{tabular}

\section{Benda Uji}

Material baja yang digunakan menggunakan data hasil uji kupon pada Tabel 2. Mutu baut yang digunakan yaitu baut A325 dengan besar tegangan tarik ultimate yaitu sebesar $825 \mathrm{MPa}$, dan proof load sebesar $635 \mathrm{MPa}$. 


\begin{tabular}{|c|c|c|c|c|}
\hline \multirow{2}{*}{ Properti } & Penggunaan & $\begin{array}{c}\text { Tegangan } \\
\text { Leleh, fy }\end{array}$ & $\begin{array}{c}\text { Tegangan } \\
\text { Tarik, fu }\end{array}$ & $\begin{array}{c}\text { Modulus } \\
\text { Elastisitas, E }\end{array}$ \\
\cline { 3 - 5 } & (MPa) & (MPa) & (MPa) \\
\hline Baja A & $\begin{array}{c}\text { Link hibrid, } \\
\text { linkstiffenerhibrid, balok, } \\
\text { kolom }\end{array}$ & 360 & 500 & 240560 \\
\hline Baja B & $\begin{array}{c}\text { Link hibrid, link stiffener } \\
\text { hibrid, end plate }\end{array}$ & 307 & 455 & 180588 \\
\hline
\end{tabular}

Elemen struktur yaitu berupa penampang IWF dimodelkan pada software MSC Patran/Nastran 2005 sebagai elemen shell sehingga dimensi penampang yang digunakan dalam pemodelan harus memperhitungkan tebal dimensi aktual dari pelat badan dan pelat sayap. Hal itu karena di dalam pemodelan, elemen struktur digambarkan sebagai garis pada titik berat pelat sayap dan badan dari penampang IWF.

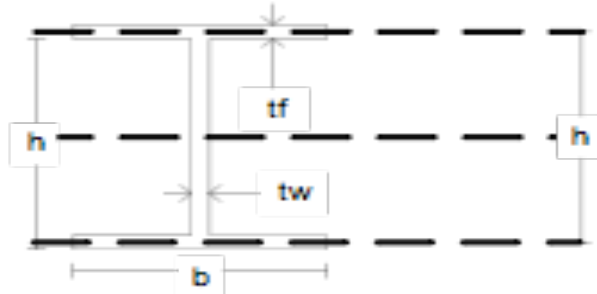

(a) Penampang

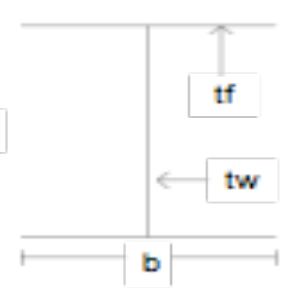

(b) Model

Gambar 4. Penampang IWF

Pelat ujung (end plate) pada sambungan las dimodelkan sebagai elemen shell, sedangkan end plate pada sambungan baut beserta baut dimodelkan sebagai elemen solid agar link berperilaku sesuai dengan spesimen yang akan diuji.

Model struktur RTE dianalisis menggunakan perletakan jepit. Pada sambungan antara balok dan kolom dan di kedua ujung link diberikan pengaku untuk mencegah terjadinya tekuk elastik dan inelastik ke arah tegak lurus bidang struktur. Pemberian kekangan pada sambungan balok kolom merepresentasikan adanya kekangan dari balok arah tegak lurus bidang struktur. Kekangan pada kedua ujung link diberikan berdasarkan persyaratan untuk struktur RTE di mana di kedua ujung link tersebut harus dipasang pengaku lateral.

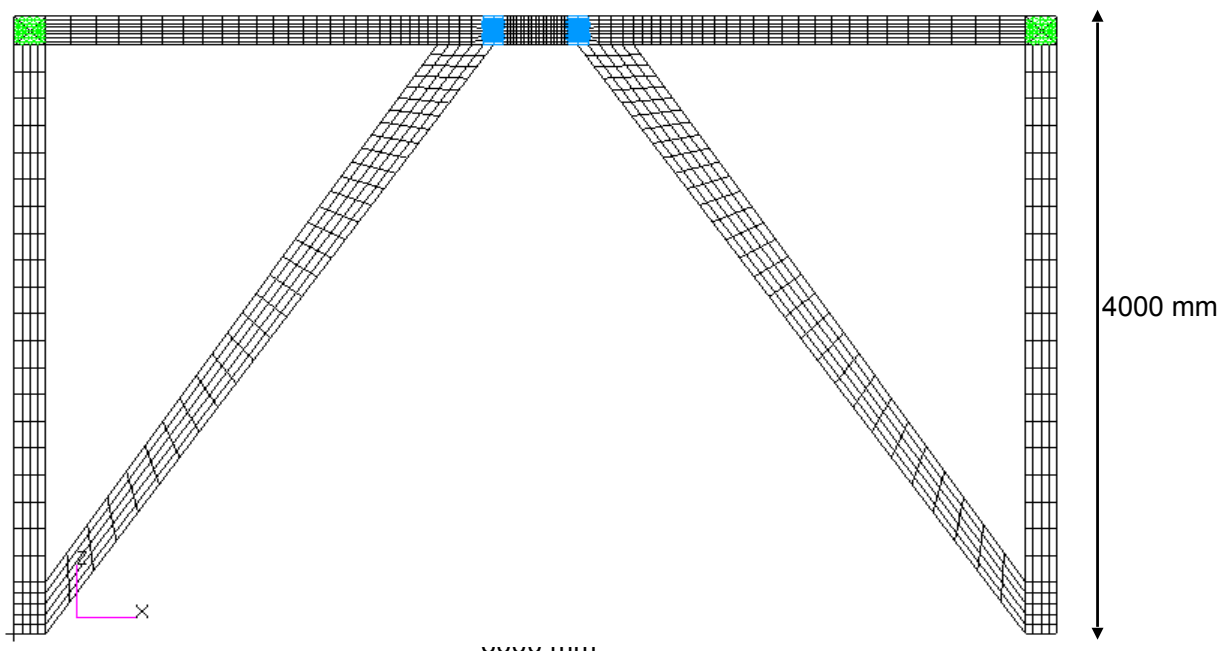

Gambar 5. Pemodelan Struktur RTE 

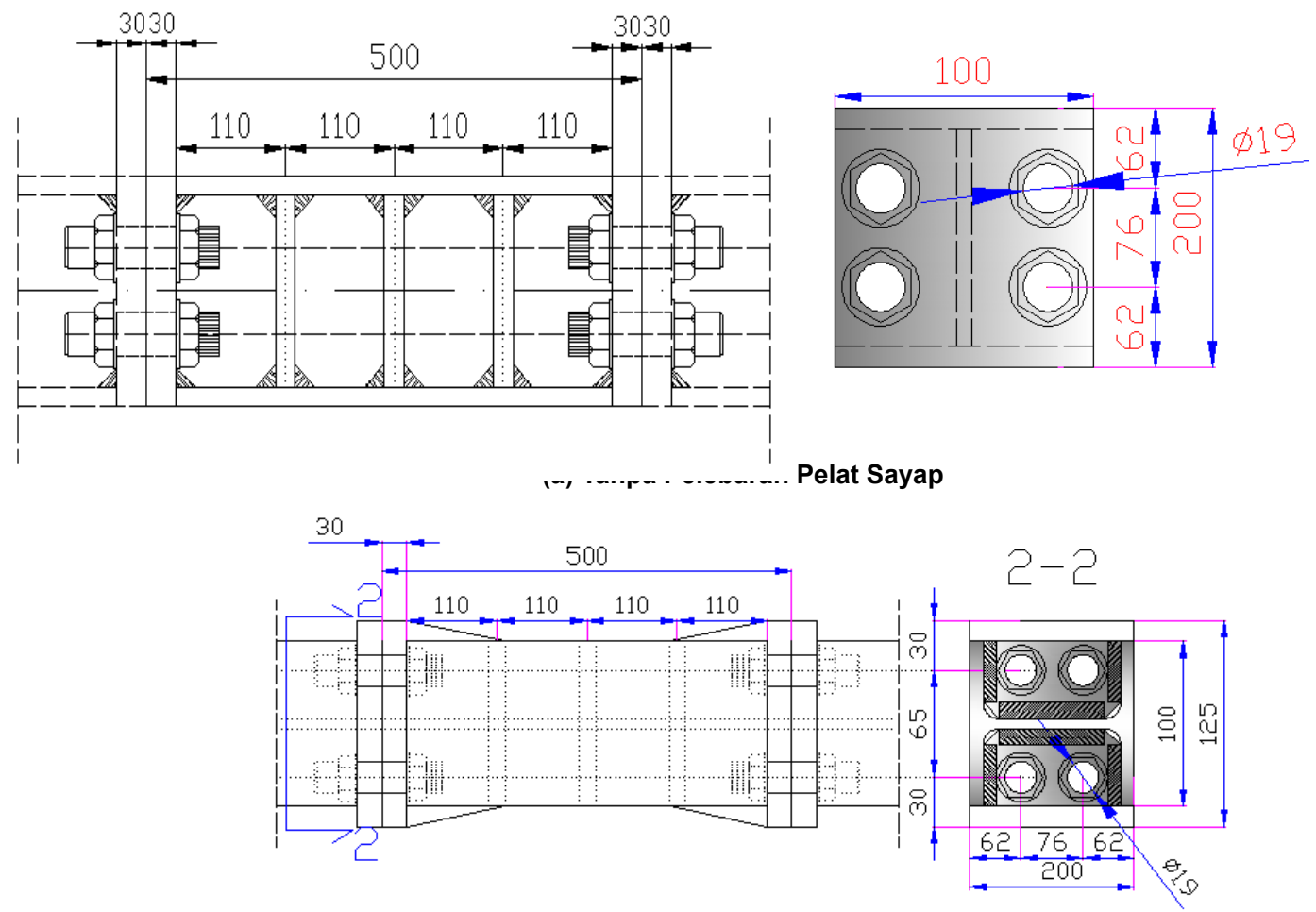

(b) Dengan Pelebaran Pelat Sayap

Gambar 6. Detail Link

Tabel 3.Penamaan Model Link

\begin{tabular}{|c|c|c|c|c|}
\hline No & Model & $\begin{array}{c}\text { Mutu pelat } \\
\text { badan, fy } \\
\text { (MPa) }\end{array}$ & $\begin{array}{c}\text { Mutu } \\
\text { pelat } \\
\text { sayap, fy } \\
\text { (MPa) }\end{array}$ & $\begin{array}{c}\text { Side } \\
\text { Extended } \\
\text { Plate (SEP) }\end{array}$ \\
\hline 1 & B. 360.360 & 360.00 & 360.00 & \multirow{4}{*}{-} \\
\hline 2 & B. 360.307 & 360.00 & 307.00 & \\
\hline 3 & B. 307.360 & 307.00 & 360.00 & \\
\hline 4 & B.307.307 & 307.00 & 307.00 & \\
\hline 5 & B.360.360 SEP & 360.00 & 360.00 & \multirow{4}{*}{$\sqrt{ }$} \\
\hline 6 & B.360.307 SEP & 360.00 & 307.00 & \\
\hline 7 & B.307.360 SEP & 307.00 & 360.00 & \\
\hline 8 & B.307.307 SEP & 307.00 & 307.00 & \\
\hline
\end{tabular}

Huruf B pada penamaan model link menunjukkan link menggunakan sambungan baut. Kumpulan angka pertama setelah huruf B yang dibatasi oleh dua tanda titik menunjukkan mutu pelat badan, dan kumpulan angka terakhir menunjukkan mutu pelat sayap. Huruf SEP di belakang kumpulan angka terakhir menunjukkan link menggunakan Side Extended Plate.

\section{Pembebanan}

Pembebanan yang diberikan terhadap benda uji ada dua tipe yaitu : statik monotonik dan kuasi statik (siklik). Pembebanan statik monotonik diaplikasikan pada struktur dengan kontrol perpindahan. Beban perpindahan diberikan di pojok kiri atas kolom dengan arah pembebanan dari kiri ke kanan. Perpindahan tersebut diberikan secara bertahap sehingga diperoleh beban pada setiap tahapan perpindahan, mulai dari terjadinya kondisi leleh pertama (first yield) hingga saat elemen struktur 
mengalami kondisi putus (ultimate). Dari hasil analisis pembebanan statik monotonik didapatkan hasil kinerja link geser yang mencakup : kekuatan (strength), kekakuan (stiffness) dan daktilitas.

Pembebanan siklik yang diaplikasikan pada struktur merupakan fungsi dari perpindahan lelehnya, mulai dari 1 kali perpindahan leleh, 2 kali perpindahan leleh dan seterusnya. Dari hasil analisis pembebanan siklik selain dapat diketahui kekuatan, kekakuan dan daktilitas struktur, juga diperoleh kemampuan link dalam mendisipasi energi dalam bentuk kurva histeresis.

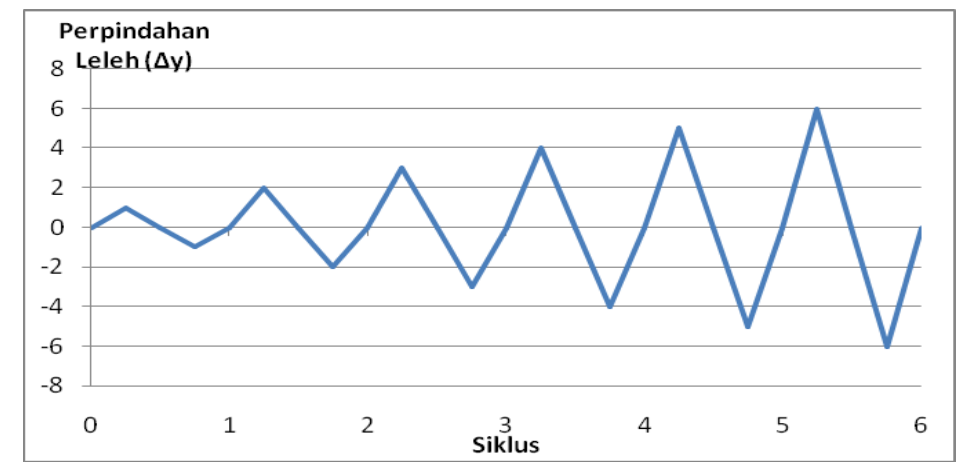

Gambar 7.Model Riwayat Pembebanan Siklik

\section{Hasil dan Analisis}

\section{Perilaku Struktur Terhadap Beban Monotonik}

\section{Analisis Kekuatan}

Tingkat kekuatan struktur bisa diketahui dengan mengaplikasikan beban statik monotonik pada struktur portal yang dikaji. Beban diaplikasikan pada struktur sampai tercapai kondisi leleh pertama (first yield) dan kondisi maksimum (ultimate). Berdasarkan konsep desain kapasitas kondisi maksimum yang ditinjau adalah kondisi dimana tercapainya beban maksimum sebelum mengalami degradasi kekuatan.

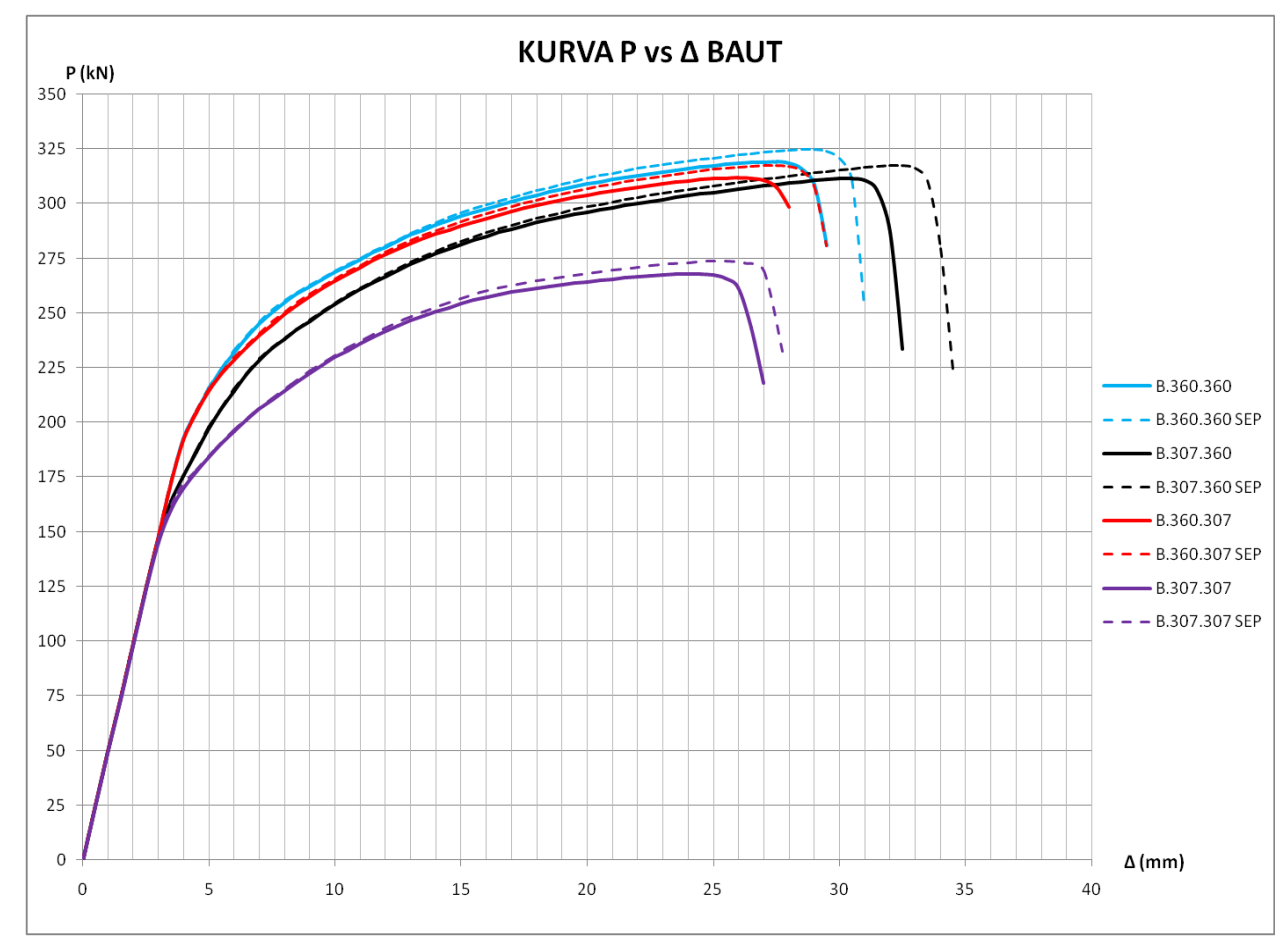

Gambar 8. Kurva Pushover Beban vs Perpindahan

Tabel 4.Perbandingan Kekuatan Struktur Antara Link Tanpa SEP dan Link Menggunakan SEP 


\begin{tabular}{|l|c|c|c|c|c|}
\cline { 3 - 5 } \multicolumn{2}{|c|}{} & Tanpa SEP & SEP & Tanpa SEP & SEP \\
\hline \multirow{3}{*}{ B.307.307 } & Beban $(k N)$ & 177.66 & 178.13 & 267.92 & 273.59 \\
\cline { 2 - 6 } & $\%$ PeningkatanKekuatan & 0 & 0.27 & 0 & 2.12 \\
\hline \multirow{3}{*}{ B.307.360 } & Beban $(k N)$ & 186.76 & 187.08 & 311.14 & 317.42 \\
\cline { 2 - 6 } & \% Peningkatan Kekuatan & 0 & 0.17 & 0 & 2.02 \\
\hline \multirow{2}{*}{ B.360.307 } & Beban (kN) & 204.71 & 205.00 & 311.73 & 317.52 \\
\cline { 2 - 6 } & \% Peningkatan Kekuatan & 0 & 0.14 & 0 & 1.86 \\
\hline \multirow{2}{*}{ B.360.360 } & Beban (kN) & 224.28 & 224.81 & 319.04 & 324.71 \\
\cline { 2 - 6 } & \% Peningkatan Kekuatan & 0 & 0.23 & 0 & 1.77 \\
\hline
\end{tabular}

Dari Gambar 8 terlihat bahwa kurva B.307.307 dan B.307.307 SEP terletak di paling bawah dari kurva model lainnya. Hal ini terjadi karena mutu pelat badan dan pelat sayap pada link yang digunakan yaitu mutu baja yang paling rendah sehingga link cepat mencapai kapasitas maksimum ketika diberi gaya lateral. Pada Tabel 4 dapat dilihat bahwa penggunaan SEP pada link dengan sambungan baut ternyata hanya menaikkan kekuatan struktur yang sangat kecil jika dibandingkan dengan penggantian mutu pelat sayap dan pelat badanlink. Hal ini disebabkan karena kekuatan struktur dalam menahan beban semakin meningkat seiring dengan peningkatan mutu baja yang digunakan.

\section{Analisis Kekakuan}

Analisis kekakuan struktur yang digunakan adalah metode secant stiffness untuk masing-masing model. Metode ini menggunakan perbandingan antara beban sebelum kondisi leleh pertama (first yield) dengan perpindahannya pada kondisi struktur masih elastik. Data yang dikaji merupakan data pushover beban terhadap perpindahan seperti pada Gambar 8. Untuk memudahkan analisis, kondisi elastik yang ditinjau yaitu pada saat kondisi sebelum leleh pertama yang mana dalam hal ini diambil besar perpindahan sebesar $3 \mathrm{~mm}$ untuk setiap model. Tabel 5 menunjukkan perhitungan kekakuan elastik struktur untuk masing-masing model.

Tabel 5. Perbandingan Kekakuan Struktur Antara Link Tanpa SEP dan Link Menggunakan SEP

\begin{tabular}{|c|c|c|c|}
\hline \multicolumn{2}{|c|}{} & Model & \multicolumn{2}{c|}{ Kekakuan Elastik } \\
\cline { 2 - 4 } & & Tanpa SEP & SEP \\
\hline \multirow{2}{*}{ B.307.307 } & Besar $(\mathrm{kN} / \mathrm{mm})$ & 48.48 & 48.75 \\
\cline { 2 - 4 } & $\%$ Peningkatan Kekakuan & 0.00 & 0.56 \\
\hline \multirow{2}{*}{ B.307.360 } & Besar $(\mathrm{kN} / \mathrm{mm})$ & 49.12 & 49.16 \\
\cline { 2 - 4 } & $\%$ Peningkatan Kekakuan & 0.00 & 0.08 \\
\hline \multirow{2}{*}{ B.360.307 } & Besar $(\mathrm{kN} / \mathrm{mm})$ & 49.34 & 49.38 \\
\cline { 2 - 4 } & $\%$ Peningkatan Kekakuan & 0.00 & 0.07 \\
\hline \multirow{2}{*}{ B.360.360 } & Besar $(\mathrm{kN} / \mathrm{mm})$ & 49.34 & 49.38 \\
\cline { 2 - 4 } & $\%$ Peningkatan Kekakuan & 0.00 & 0.07 \\
\hline
\end{tabular}

Berdasarkan Tabel 5 terlihat tidak terjadi perubahan yang signifikan besarnya kekakuan struktur elastik yang terjadi pada setiap model sehingga memiliki kekakuan yang baik.

\section{Faktor Kuat Lebih (Overstrength Ratio)}


Faktor kuat lebih dipengaruhi oleh perbandingan antara kekuatan ultimate yang dicapai dengan kekuatan pada saat kondisi leleh pertama (first yield). Besarnya faktor kuat lebih untuk keseluruhan model dapat dilihat pada Tabel 6.

Tabel 6.Overstrength Ratio

\begin{tabular}{|c|c|c|c|c|c|c|}
\hline No & Model & $\begin{array}{c}\mathbf{P m a x} \\
\mathbf{( k N )}\end{array}$ & $\mathbf{P y} \mathbf{( k N )}$ & $\begin{array}{c}\Delta \mathbf{m a x} \\
(\mathbf{m m})\end{array}$ & $\begin{array}{c}\Delta \mathbf{y} \\
(\mathbf{m m})\end{array}$ & $\begin{array}{c}\text { Overstrength } \\
\text { Ratio }\end{array}$ \\
\hline 1 & B.307.307 & 267.92 & 177.66 & 24 & 4.5 & 1.51 \\
\hline 2 & B.307.360 & 311.14 & 200.76 & 30.5 & 4.5 & 1.55 \\
\hline 3 & B.360.307 & 311.73 & 204.71 & 26 & 4.5 & 1.52 \\
\hline 4 & B.360.360 & 319.04 & 224.28 & 27.5 & 5.5 & 1.42 \\
\hline 5 & B.307.307 SEP & 273.59 & 178.13 & 24.75 & 4.5 & 1.54 \\
\hline 6 & B.307.360 SEP & 317.42 & 201.08 & 32.5 & 4.5 & 1.58 \\
\hline 7 & B.360.307 SEP & 317.52 & 205.00 & 27.5 & 4.5 & 1.55 \\
\hline 8 & B.360.360 SEP & 324.71 & 224.81 & 29 & 5.5 & 1.44 \\
\hline
\end{tabular}

Tabel 6 menunjukkan ternyata tidak ada model yang nilai overstrength ratio-nya di bawah nilai overstrength material yang sebesar 1,1 serta overstrength elemen struktur di luar link (balok dan kolom sebesar 1,1 serta bracing sebesar 1.25) yang dipakai pada waktu mendesain elemen RTE. Hal ini berarti struktur yang didesain berada dalam kondisi aman.

\section{Rotasi Link}

Di dalam merencanakan struktur RTE, SNI 1729:2015 mensyaratkan bahwa elemen link harus mampu untuk mengalami rotasi plastik $\left(\gamma_{p}\right)$ yang cukup besar. Rotasi link dihitung dari kondisi maksimum di mana terjadi kelelehan pertama pada komponen struktur di luar link. Untuk menghitung sudut rotasi link digunakan rumus (4) dan (5).

Tabel 7. Rotasi Link Beban Monotonik

\begin{tabular}{|c|c|c|c|c|c|}
\hline No & Model & $\begin{array}{c}\text { Panjang } \\
\text { Link } \\
(\mathbf{m m})\end{array}$ & $\begin{array}{c}\text { Panjang } \\
\text { Bentang } \\
(\mathrm{mm})\end{array}$ & $\begin{array}{c}\text { Perpindahan } \\
\text { Maksimum, } \\
\Delta \mathbf{p}(\mathrm{mm})\end{array}$ & Rotasi Link, $\gamma p$ (rad) \\
\hline 9 & B.360.307 SEP & \multirow{8}{*}{500} & \multirow{8}{*}{6000} & 27.50 & 0.165 \\
\hline 10 & B.360.307 & & & 29.00 & 0.174 \\
\hline 11 & B.360.360 SEP & & & 30.50 & 0.183 \\
\hline 12 & B. 360.360 & & & 32.50 & 0.195 \\
\hline 13 & B.307.360 SEP & & & 26.00 & 0.156 \\
\hline 14 & B. 307.360 & & & 27.50 & 0.165 \\
\hline 15 & B.307.307 SEP & & & 24.00 & 0.144 \\
\hline 16 & B.307.307 & & & 24.75 & 0.149 \\
\hline
\end{tabular}

Semua model menunjukkan melampaui batas kinerja maksimum di mana rotasi link melebihi batas rotasi inelastik yang disyaratkan untuk struktur RTE dengan perilaku link geser yaitu sebesar 0,08 radian.Besarnya rotasi inelastik mampu dilampaui sebelum terjadi kelelehan pada elemen struktur lain selain link. 


\section{Analisis Daktilitas}

Daktilitas struktur menggambarkan kemampuan struktur untuk berdeformasi inelastik tanpa kehilangan kekuatan yang signifikan. Daktilitas terhadap struktur merupakan perbandingan antara perpindahan pada saat elemen link mencapai kondisi ultimate dengan perpindahan elemen link pada saat mengalami kelelehan untuk pertama kali (first yield).

Pada struktur RTE, daktilitas struktur ditentukan oleh daktilitas elemen link dalam mengalami rotasi inelastik yang besar sebelum mengalami kegagalan yaitu sampai dengan kondisi ultimate.

Tabel 8. Perbandingan Daktilitas Struktur Dengan dan Tanpa SEP

\begin{tabular}{|c|c|c|c|}
\hline \multicolumn{2}{|c|}{} & \multirow{2}{*}{ Model } & \multicolumn{2}{c|}{ Daktilitas } \\
\cline { 2 - 4 } & Banpa SEP & SEP \\
\hline \multirow{2}{*}{ B.307.307 } & Besar Daktilitas & 5.33 & 5.50 \\
\cline { 2 - 4 } & $\%$ Peningkatan Daktilitas & 0 & 3.13 \\
\hline \multirow{2}{*}{ B.307.360 } & Besar Daktilitas & 6.78 & 7.22 \\
\cline { 2 - 4 } & $\%$ Peningkatan Daktilitas & 0 & 6.56 \\
\hline \multirow{2}{*}{ B.360.307 } & Besar Daktilitas & 5.78 & 6.11 \\
\cline { 2 - 4 } & $\%$ Peningkatan Daktilitas & 0.00 & 5.77 \\
\hline \multirow{2}{*}{ B.360.360 } & Besar Daktilitas & 5.00 & 5.27 \\
\cline { 2 - 4 } & $\%$ Peningkatan Daktilitas & 0 & 5.45 \\
\hline
\end{tabular}

Dari Tabel 8 dapat dilihat bahwa apabila model tanpa SEP dibandingkan dengan model yang menggunakan SEP, diperoleh hasil model B.307.360 menjadi lebih daktail apabila diberi SEP. Fenomena ini terjadi karena dengan adanya penambahan SEP maka tegangan maksimum Von Misses yang terjadi pada pelat sayap menjadi semakin kecil. Karena luas pelat sayap untuk menahan tarik dan tekan menjadi semakin besar maka dihasilkan tegangan yang lebih kecil. Karena tegangan yang terjadi lebih kecil maka terjadinya kegagalan (tekuk) pada pelat sayap dapat ditunda. Luas pelat sayap yang semakin besar menyebabkan tegangan tarik dan tekan dapat lebih disebarkan ke area yang lebih luas dan juga semakin menjamin penyebaran tegangan dari panel tepi ke panel tengah sehingga semakin menjamin kegagalan geser pada pelat badan.

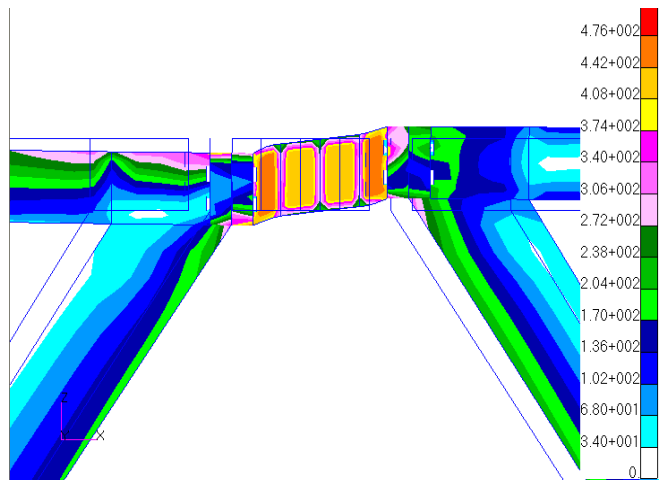

(a) Link, Balok, Bracing

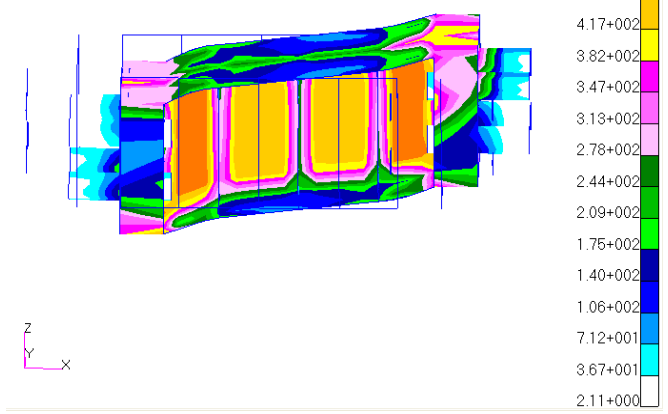

(b) Link 


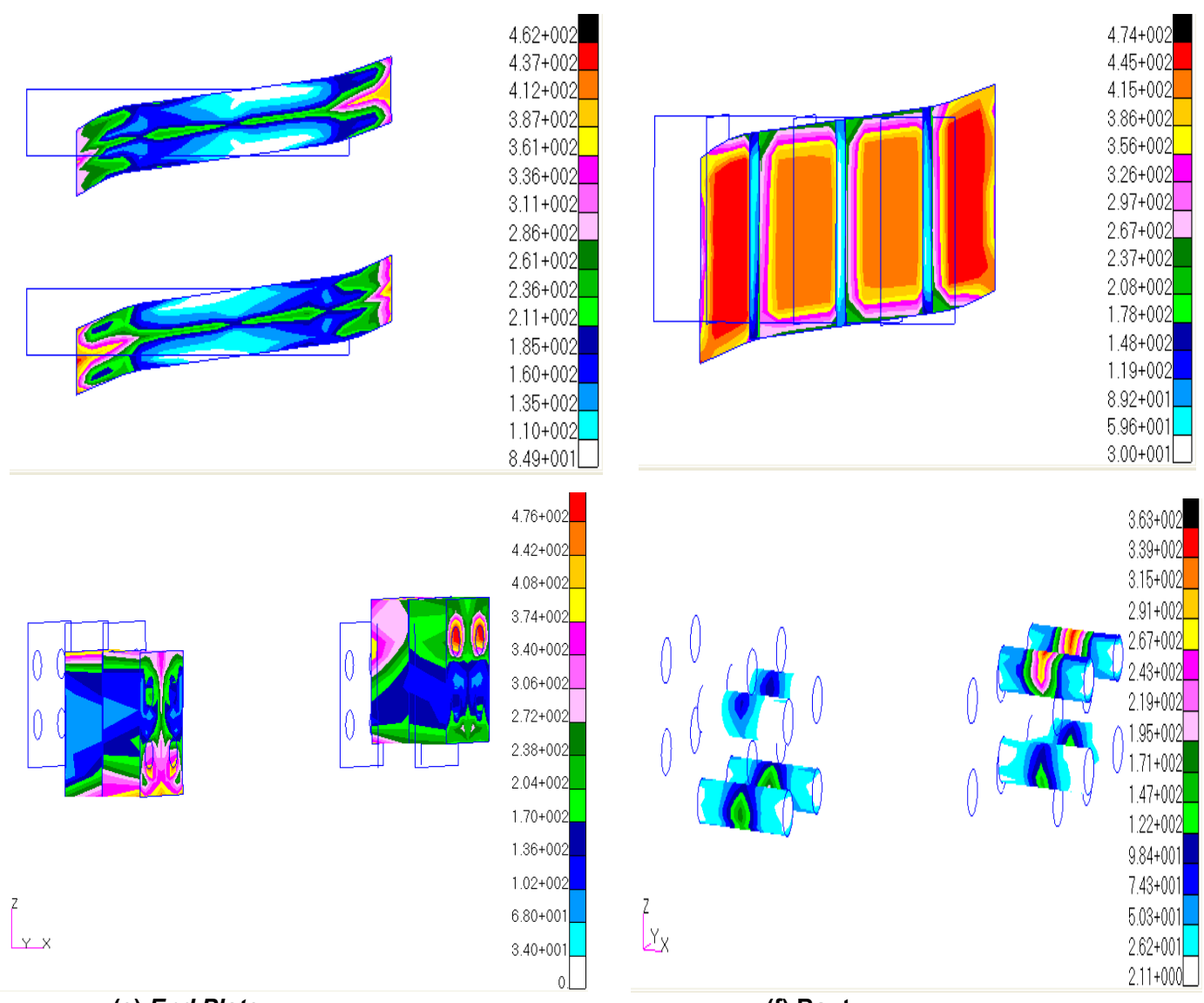

(e) End Plate

(f) Baut

Gambar 9. Kontur tegangan Von Misses Link Model B.307.360 Kondisi Ultimate

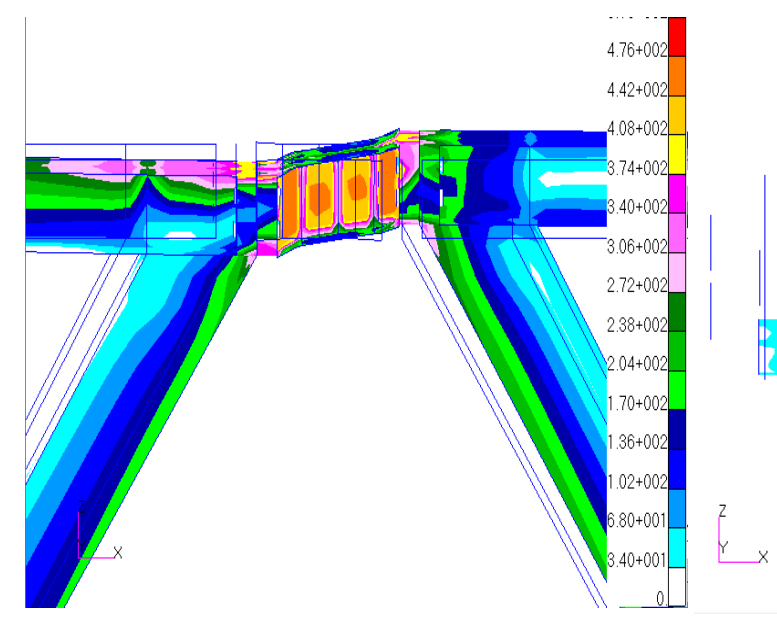

(a) Link, Balok, Bracing

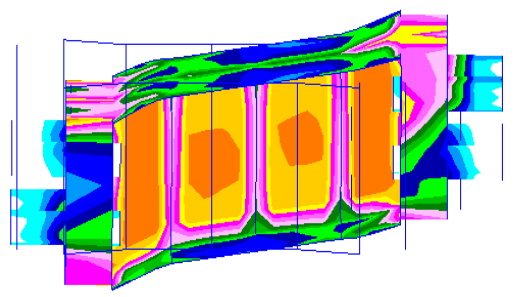

$4.76+002$
$4.42+002$
$4.08+002$
$3.74+002$
$3.40+002$
$3.06+002$
$2.72+002$
$2.38+002$
$2.04+002$
$1.70+002$
$1.36+0022$
$1.02+002$
$6.80+001$
$3.40+001$

(b) Link 


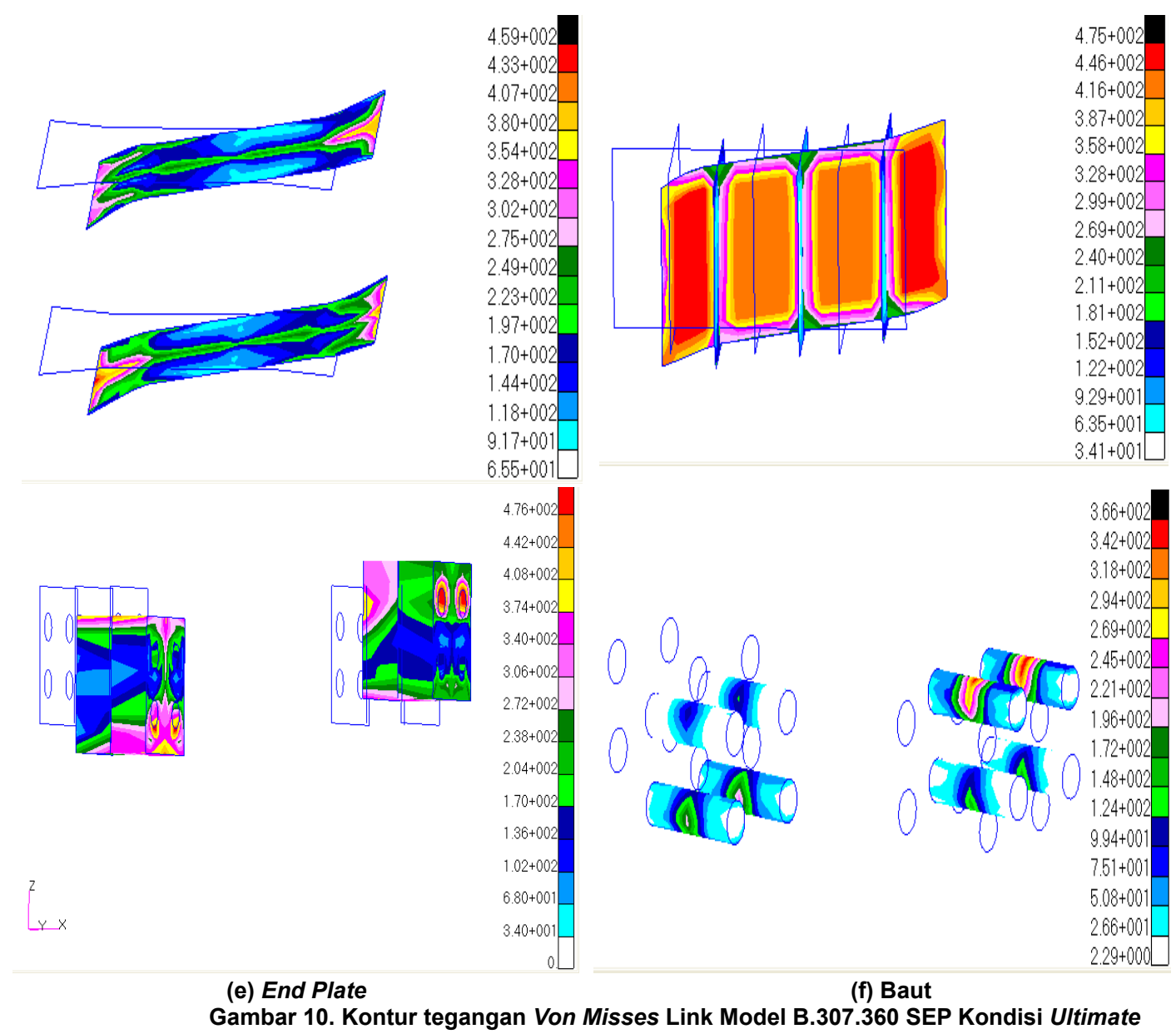

Penggantian mutu pelat sayap dan pelat badan link berdasarkan Tabel 8 lebih berpengaruh secara signifikan dibandingkan penggunaan SEP. Hal ini terjadi karena dengan digunakannya mutu pelat sayap yang lebih tinggi maka tegangan Von Misses yang terjadi pada pelat sayap menjadi semakin kecil. Tegangan yang lebih kecil ini menyebabkan penundaan terjadinya tekuk pada pelat sayap akibat lebih tingginya mutu pelat sayap. Penggunaan mutu pelat sayap yang lebih tinggi juga dapat menjamin penyebaran tegangan pada pelat badan dari serat atas ke serat tengah sehingga semakin menjamin kegagalan geser pada pelat badan.

Dari Tabel 8 dapat diambil informasi urutan daktilitas struktur dimulai dari yang paling besar yaitu : B. 307.360 SEP > B.307.360 > B.360.307 SEP > B.360.307 > B.307.307 SEP > B.307.307 > B.360.360 SEP > B.360.360.

\section{Perilaku Struktur Terhadap Beban Monotonik}

\section{Energi Disipasi}

Di dalam struktur RTE, tempat untuk mendisipasi energi terletak pada link. Oleh karena itu link harus bersifat daktail agar dapat mendisipasi energi lebih banyak.Energi regangan yang terdisipasi pada elemen link yang dibebani secara siklik dapat dihitung melalui kurva histeresis. Dari kurva histeresis versus perpindahan dapat dihitung luasan yang terbentuk setiap siklusnya untuk mendapatkan besarnya energi disipasi. 


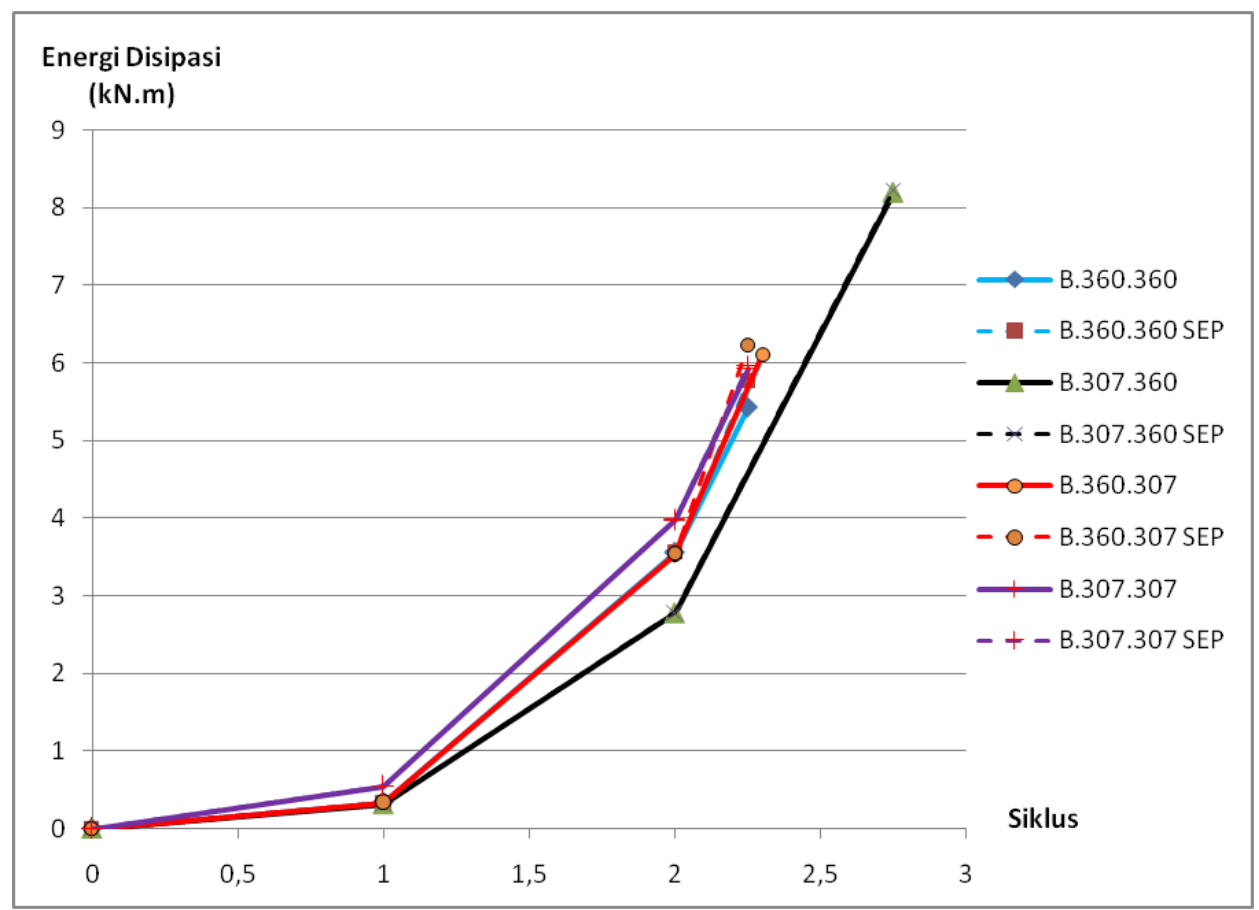

Gambar 11. Kurva Energi Disipasi Link

Dari Gambar 11 dapat dilihat bahwa ada 2 model (B.307.360 SEP dan B.307.360) yang mampu menghasilkan kurva histeresis hingga mendekati akhir siklus ke-3 dibandingkan model lainnya. Model B.307.360 SEP mempunyai energi disipasi yang paling besar dibandingkan model lainnya di mana jika dilihat pada gambar, letak kurva berhimpit dengan model B.307.360. Oleh karena itu model B. 307.306.SEP dan B.307.306 merupakan model yang paling baik di dalam mendisipasi energi.

\section{Rotasi Link}

Rotasi link yang dihitung yaitu pada saat siklus terakhir tepat pada saat titik runtuh. Besar sudut rotasi link bisa dihitung dengan pendekatan sudut tangen.

(6)

$$
\gamma_{p}=\frac{\llbracket z k i \|+z k a}{\text { Panjang link }}
$$

Keterangan :

$\mathrm{Z} \mathrm{ki} \quad$ : Perpindahan vertikal pada ujung link di sisi kiri

Z ka : Perpindahan vertikal pada ujung link di sisi kanan

$\Delta \mathrm{X} \mathrm{ki}$ : Perpindahan horizontal pada ujung link di sisi kiri

$\Delta \mathrm{X}$ ka : Perpindahan horizontal pada ujung link di sisi kanan

Tabel 9. Rotasi Link Beban Siklik Pada Link Dengan Sambungan Baut

\begin{tabular}{|c|c|c|c|c|c|c|c|}
\hline \multirow{2}{*}{ No } & \multirow{2}{*}{ Model } & \multicolumn{6}{|c|}{ Kondisi Ultimate } \\
\cline { 3 - 8 } & & $\mathbf{Z ~ k i}$ & $\mathbf{Z ~ k a}$ & $\Delta \mathbf{X ~ k i}$ & $\Delta \mathbf{X}$ ka & $\begin{array}{c}\text { Panjang } \\
\text { Link (mm) }\end{array}$ & $\gamma_{\mathbf{u}}$ \\
\hline 1 & B.360.360 & -6.78 & 5.68 & 12.22 & 11.17 & 498.95 & 0.050 \\
\hline 2 & B.360.360 SEP & -7.89 & 6.49 & 13.52 & 12.11 & 498.60 & 0.058 \\
\hline
\end{tabular}




\begin{tabular}{|c|c|c|c|c|c|c|c|}
\hline \multirow{2}{*}{ No } & \multirow{2}{*}{ Model } & \multicolumn{5}{|c|}{ Kondisi Ultimate } \\
\cline { 3 - 8 } & & $\mathbf{Z ~ k i}$ & $\mathbf{Z ~ k a}$ & $\Delta \mathbf{X ~ k i}$ & $\Delta \mathbf{X}$ ka & $\begin{array}{c}\text { Panjang } \\
\text { Link (mm) }\end{array}$ & $\gamma_{\mathbf{u}}$ \\
\hline 3 & B.360.307 & -6.44 & 6.47 & 12.57 & 12.41 & 499.84 & 0.052 \\
\hline 4 & B.360.307 SEP & -6.47 & 6.47 & 12.63 & 12.40 & 499.78 & 0.052 \\
\hline 5 & B.307.360 & -5.96 & 5.07 & 11.10 & 10.28 & 499.18 & 0.044 \\
\hline 6 & B.307.360 SEP & -8.44 & 6.52 & 13.20 & 11.09 & 497.89 & 0.060 \\
\hline 7 & B.307.307 & -2.88 & 2.60 & 6.68 & 6.48 & 499.80 & 0.022 \\
\hline 8 & B.307.307 SEP & -3.99 & 3.44 & 7.97 & 7.51 & 499.54 & 0.030 \\
\hline
\end{tabular}

Semua model menunjukkan tidak melampaui batas kinerja maksimum di mana rotasi link ketika mengalami beban siklik tidak melebihi batas rotasi inelastik yang disyaratkan SNI untuk struktur RTE dengan perilaku link geser yaitu sebesar 0,08 radian.

\section{Kesimpulan}

Dari hasil kajian numerik yang dilakukan pada delapan buah model dengan variasi pada mutu pelat sayap dan pelat badan pada link serta penambahan Side Extended Plate (SEP) diperoleh beberapa kesimpulan sebagai berikut:

1. Penggantian mutu baja pada pelat sayap dan pelat badan link lebih dapat meningkatkan kekuatan, kekakuan dan daktilitas struktur secara signifikan jika dibandingkan dengan penggunaan Side Extended Plate (SEP).

2. Dari hasil analisis terhadap beban monotonik, model yang menggunakan mutu tinggi ( $\mathrm{fy}=360$ $\mathrm{MPa}$ ) pada pelat badan dan pelat sayap serta menggunakan Side Extended Plate (SEP) memiliki kekuatan dan kekakuan paling baik. Namun, model yang menggunakan mutu pelat sayap lebih tinggi daripada mutu pelat badan serta menggunakan Side Extended Plate (SEP) memiliki faktor kuat lebih dan daktilitas yang paling baik.

3. Dari hasil analisis terhadap beban siklik, model link hibrid dengan mutu pelat sayap lebih tinggi daripada mutu pelat badanmampu mendisipasi energi yang paling baik, baik yang dengan menggunakan Side Extended Plate (SEP) maupun tanpa menggunakan SEP.

4. Penggunaan Side Extended Plate (SEP) dapat meningkatkan kekuatan, kekakuan dan daktilitas struktur serta disipasi energi dibanding dengan link yang tidak menggunakan SEP.

5. Pelebaran pelat sayap telah mengurangi tegangan yang terjadi pada pelat sayap dan pelat ujung. Hal tersebut sangat membantu penundaan kelelehan pada perbatasan pelat sayap dan pelat ujung sehingga menjamin kelelehan yang lebih optimal pada pelat badan.

6. Sudut rotasi link pada kondisi ultimate untuk semua model yang dikaji pada pembebanan monotonik melampaui batas kinerja link yang disyaratkan peraturan pada SNI 1729:2015 yaitu sebesar 0,08 radian.

\section{Daftar pustaka}

[1] Kasai, K. dan Popov, E.P. "General behaviour of WF steel shear link beams," Journal of the Structural Division ASCE, 112:2, 362-382, 1986.

[2] Moestopo, M. dan Mirza, A. "Kinerja Sambungan Baut pada Link Struktur Rangka Baja Eksentrik," Seminar \& Pameran HAKI, 2006

[3] Moestopo, M., D. Kusumastuti. dan A. Novan. "Improved Performance of Bolt-Connected Link Due To Cyclic Load," International Conference on Earthquake Engineering and Disaster Mitigation, 2009

[4] Moestopo, M. dan M. A. R. Panjaitan. "Kajian Eksperimental Peningkatan Kinerja Link Geser pada Sistem Rangka Baja Berpengaku Eksentrik,"Jurnal Teknik Sipil Vol. 19 No. 2 Agustus 2012. 
[5] Moestopo, M., A. Novan, A. Mirza, A. R. Pandjaitan, W. Y. Utomo. "On Improved Performance of Eccentrically Braced Frames with Replaceable Shear Link," The 15th World Conference on Earthquake Engineering, 2012.

[6] Pembebanan untuk Perancangan Bangunan Gedung dan Struktur Lain, SNI 1727:2013.

[7] Perencanaan Ketahanan Gempa untuk Struktur Bangunan Gedung dan Non Gedung, SNI 1726:2012.

[8] Spesifikasi untuk Bangunan Gedung Baja Struktural, SNI 1729:2015. 